\title{
De werkplek thuis, bezien in het licht van COVID-19
}

\author{
Breekt nood wet of maken we van de nood een deugd? De werkplek thuis is niet voor \\ iedereen een vreugd
}

mr. Simone Drost en mr. Willemijn Bosman*

\section{Inleiding}

Inmiddels houdt COVID-19 ons al ruim een jaar in de greep. Aanvankelijk leidde dit op arbeidsrechtelijk gebied met name tot vragen over de mogelijkheid van de werkgever om eenzijdig vakantiedagen vast te stellen en over hoe om te gaan met een reeds door de werknemer geplande vakantie. COVID-19 heeft echter ook enorme consequenties voor de werkplek. Het advies van de Rijksoverheid luidt al geruime tijd 'Werk thuis, tenzij het niet anders kan'. Als gevolg daarvan wordt veel thuisgewerkt. Verwacht wordt dat ook na de COVID-19pandemie veel werknemers (al dan niet gedeeltelijk) thuis blijven werken. ${ }^{1}$

In dit artikel gaan wij in op relevante regelgeving, jurisprudentie, literatuur en nieuwsberichten omtrent thuiswerken. ${ }^{2}$ We bespreken de Wet flexibel werken en andere mogelijkheden om aanpassing van de arbeidsplaats te verzoeken, waarbij ook het wetsvoorstel Wet werken waar je wilt ${ }^{3}$ aan bod komt. Voorts komt aan de orde of er een recht op en/of een plicht tot thuiswerken bestaat en in hoeverre thuiswerken een rol kan spelen bij ontslag. Tot slot behandelen we welke verplichtingen uit de Arbowetgeving en het Burgerlijk Wetboek volgen ten aanzien van de werkplek thuis en wat de reikwijdte van deze wetgeving is.
Simone Drost en Willemijn Bosman zijn beiden Senior Legal Counsel Arbeidsrecht bij ABN Amro.

1. 'Thuiswerken vóór, tijdens en ná de coronacrisis', Centraal Planbureau, januari 2021

2. Wij hebben literatuur, jurisprudentie etc. betrokken tot begin juni 2021.

3. Voorstel van wet van de leden Van Weyenberg en Maatoug tot wijziging van de Wet flexibel werken in verband met het bevorderen van flexibel werken naar arbeidsplaats (Wet werken waar je wilt).

\section{Werkplek thuis}

\subsection{Wet flexibel werken}

De Wet flexibel werken $(\mathrm{Wfw})^{4}$ biedt de werknemer de mogelijkheid om een wijziging te verzoeken in de overeengekomen arbeidsduur, werktijd en arbeidsplaats. ${ }^{5}$ De werknemer dient ten minste een halfjaar bij de werkgever in dienst te zijn op het moment van de beoogde wijziging en het verzoek tot wijziging moet ten minste twee maanden voor de beoogde wijziging schriftelijk worden ingediend.

De werkgever moet het verzoek van de werknemer om aanpassing van de arbeidsplaats overwegen en over een afwijzing daarvan met de werknemer overleggen. ${ }^{6}$ De beslissing dient schriftelijk (in geval van afwijzing gemotiveerd) aan de werknemer te worden medegedeeld. Indien de werkgever niet ten minste een maand voor de beoogde wijziging op het verzoek heeft beslist, wordt de arbeidsplaats aangepast overeenkomstig het verzoek van de werknemer.

Zwaarwegende bedrijfs- of dienstbelangen spelen derhalve, anders dan bij verzoeken om wijziging van arbeidsduur en werktijd, geen rol bij de beoordeling van het verzoek van een werknemer om aanpassing van de arbeidsplaats. Er is slechts sprake van een 'duty to consider' van de werkgever. De lat om een dergelijk verzoek van de werknemer af te wijzen ligt dus niet hoog. Achterliggende reden is dat een wijziging van de arbeidsplaats doorgaans ingrijpender is voor de arbeidsverhouding dan een wijziging van de urenomvang en/of de spreiding van de uren. ${ }^{7}$ De werkgever is immers, bijvoorbeeld, verantwoordelijk voor de arbeidsomstandigheden, waarover later in dit artikel meer.

Werknemers maken weinig gebruik van de mogelijkheid om op grond van de Wfw een verzoek tot flexibel wer-

4. De Wfw is de opvolger van de Wet aanpassing arbeidsduur (Waa), die louter zag op de arbeidsduur en de spreiding van de uren.

5. De Wfw is niet van toepassing op werkgevers met minder dan tien werknemers. Bij cao kan van de Wfw worden afgeweken.

6. Art. 2 lid $6 \mathrm{Wfw}$. Onder arbeidsplaats wordt verstaan: iedere overeengekomen plaats die in verband met het verrichten van arbeid wordt of pleegt te worden gebruikt door de werknemer (art. 1 sub d Wfw).

7. Kamerstukken // 2014/15, 32889, nr. 17 
ken in te dienen, blijkt uit het recent gepubliceerde evaluatieonderzoek van de Wfw. ${ }^{8}$ Uit de betreffende evaluatie volgt dat werknemers enerzijds onvoldoende bekend zijn met de mogelijkheden die de Wfw biedt, en dat zij er anderzijds in goed onderling overleg met hun werkgevers uitkomen. Er is ook weinig jurisprudentie over dit onderwerp. In de jurisprudentie die er is, trekt de werknemer doorgaans aan het kortste eind. ${ }^{9}$ Indien een werkgever wenst terug te komen op een beslissing ten aanzien van een wijziging van de arbeidsplaats, kan dat indien sprake is van na die beslissing opgekomen belangen. ${ }^{10}$ Ook dan hoeft derhalve geen sprake te zijn van zwaarwegende bedrijfs- of dienstbelangen, zoals bij een herziening in het kader van de arbeidstijd.

\subsection{Goed werkgeverschap en goed werknemerschap}

Naast een verzoek op grond van de Wfw kan een werknemer ook op grond van artikel 7:611 BW (beginsel van goed werkgeverschap) een voorstel tot wijziging van de arbeidsplaats doen. ${ }^{11}$ De werkgever zal een belangenafweging moeten maken en afhankelijk van de omstandigheden van het geval met een dergelijk verzoek moeten instemmen. ${ }^{12}$

Ten Broeke en Baijens merken op dat de beoordeling van een verzoek om aanpassing van de arbeidsplaats op grond van artikel 7:611 $\mathrm{BW}$ in het licht van de normen van de Wfw dient te worden beoordeeld. ${ }^{13} \mathrm{Uit}$ de $\mathrm{Wfw}$ volgt geen hard recht op thuiswerken. De redelijkheidstoets van artikel 7:611 BW leidt er met de Wfw in het achterhoofd toe dat moet worden getoetst of afwijzing van het verzoek van de werknemer naar maatstaven van redelijkheid en billijkheid onaanvaardbaar is voor de werknemer en niet of een toewijzing naar maatstaven van redelijkheid en billijkheid onaanvaardbaar is voor de werkgever, aldus Ten Broeke en Baijens. Hoewel geen wettelijke eisen gelden voor de motivering van afwijzing van het verzoek tot wijziging van de arbeidsplaats, blijkt uit de (summiere) jurisprudentie dat de redenen van de afwijzing wel degelijk een rol spelen. Argumenten die een rol kunnen spelen zijn de aard van de werkzaamheden, de belangen van andere werknemers, de instructiebevoegdheid en zorgplicht van de werkgever, het functioneren van de werknemer en de bedrijfseconomische situatie van de werkgever. ${ }^{14}$

Thuiswerken kan ook een arbeidsvoorwaarde zijn (geworden), bijvoorbeeld als het recht daarop is opge-

8. De Beleidsonderzoekers, Evaluatie Wet flexibel werken, Onderzoek voor het Ministerie van SZW, 15 januari 2021.

9. Zie bijv. Rb. Amsterdam 11 november 2018, ECLI:NL:RBAMS: 2018:7998

10. Art. 2 lid $13 \mathrm{Wfw}$

11. Zie bijv. Ktr. Nijmegen 16 juni 2020, ECLI:NL:RBGEL:2020:2954.

12. HR 8 november 2019, ECLI:NL:HR:2019:1734.

13. Ktr. Nijmegen 16 juni 2020, ECLI:NL:RBGEL:2020:2954, JAR 2020/169, m.nt. M. ten Broeke en I. Baijens, p. 1672.

14. Zie bijv. Ktr. Nijmegen 16 juni 2020, ECLI:NL:RBGEL:2020:2954, JAR 2020/169, m.nt. M. ten Broeke en I. Baijens, p. 1672; Rb. Amsterdam 6 november 2018, ECLI:NL:RBAMS:2018:7998 en Hof Amsterdam 30 januari 2018, ECLI:NL:GHAMS:2018:317. nomen in de arbeidsovereenkomst of door verloop van tijd is ontstaan. In geval van een eenzijdig wijzigingsbeding zal een door de werkgever gewenste wijziging van de arbeidsplaats moeten worden beoordeeld aan de hand van artikel 7:613 BW. Indien geen eenzijdig wijzigingsbeding is overeengekomen, dan geldt artikel 7:611 BW en de maatstaf van de Hoge Raad uit het Stoof/Mammoet-arrest. ${ }^{15}$ Onderzocht dient te worden of de werkgever als goed werkgever in de wijziging van de omstandigheden aanleiding heeft kunnen vinden voor het doen van een voorstel tot wijziging van de arbeidsvoorwaarde, en of het door de werkgever gedane voorstel redelijk is. Daarbij dienen alle omstandigheden van het geval in aanmerking te worden genomen, waaronder de aard van de gewijzigde omstandigheden die tot het voorstel aanleiding hebben gegeven en de aard en ingrijpendheid van het gedane voorstel, alsmede de positie van werknemer en het belang van de werknemer bij het ongewijzigd blijven van de arbeidsvoorwaarde. Indien van een redelijk voorstel sprake is, dient vervolgens nog te worden onderzocht of aanvaarding van dat voorstel in het licht van de omstandigheden van het geval in redelijkheid van werknemer gevergd kan worden. ${ }^{16}$

Inmiddels wordt in bepaalde sectoren al meer dan een jaar zonder problemen thuisgewerkt. Hoe langer deze situatie voortduurt, hoe meer een werkgever zal moeten onderbouwen waarom thuiswerken niet langer tot de mogelijkheden behoort. Een enkele overdenking volstaat niet. $^{17}$

\subsection{Wetsvoorstel Wet werken waar je wilt ${ }^{18}$}

Op 19 november 2020 is het wetsvoorstel Wet werken waar je wil ${ }^{19}$ ter internetconsultatie aangeboden. De internetconsultatie is op 18 december 2020 gesloten en het wetsvoorstel is op 27 januari 2021 aan de Tweede Kamer aangeboden. ${ }^{20}$ De initiatiefnemers menen dat na de COVID-19-pandemie een nieuw evenwicht zal moeten worden gevonden tussen thuiswerken en het werken op een werklocatie of een andere werkplek. Zij achten het recht op thuiswerken en het werken op een werklocatie in die zin even belangrijk. Het recht op aanpassing van de arbeidsplaats is evenwel minder goed verankerd in de wet dan het recht op aanpassing van de arbeidsduur en werktijd, aldus de initiatiefnemers. ${ }^{21}$ Het wetsvoorstel levert volgens hen een bijdrage aan het faciliteren van de dialoog tussen werkgever en werknemer.

Het wetsvoorstel ziet op een wijziging van de $\mathrm{Wfw}$ en beoogt het beoordelingskader van het verzoek om

15. HR 11 juli 2008, ECLI:NL:HR:2008:BD1847.

16. Zie ook S.R. Sripal, 'Wijziging van primaire arbeidsvoorwaarden in tijden van crises op grond van art. 7:613 BW', TAP 2021/86.

17. A.R. Houwelling, 'Corona en arbeidsrecht: hoe NOW verder met loon en werkplek?!', MvV 2020, nr. 9.

18. Voorstel van wet van de leden Van Weyenburg en Smeulders tot wijziging van de Wet flexibel werken in verband met het bevorderen van flexibel werken naar arbeidsplaats (Wet werken waar je wil).

19. De naam van het wetsvoorstel is inmiddels aangepast naar 'Wet werken waar je wilt'.

20. Kamerstukken I/ 2020/21, 35714, nr. 2

21. Kamerstukken // 2020/21, 35714, nr. 3. 
wijziging van de arbeidsplaats door de werknemer gelijk te stellen aan dat van verzoeken ten aanzien van arbeidsduur en werktijd. Met andere woorden, ook een voorstel tot wijziging van de arbeidsplaats zou ingewilligd moeten worden, tenzij sprake is van zwaarwegende bedrijfsof dienstbelangen. De initiatiefnemers menen dat de extra kosten die het voorstel voor de werkgever met zich brengt in het kader van bijvoorbeeld Arbowetgeving (ruimschoots) gecompenseerd zullen worden door de verminderde reiskostenvergoeding. Een onderbouwing daarvan ontbreekt evenwel.

Wij plaatsen kanttekeningen bij de voorgestelde anpassing van de $\mathrm{Wfw}^{22}$ Ten eerste bestaat er weinig jurisprudentie over dit onderwerp, hetgeen impliceert dat werkgevers en werknemers over het algemeen onderling tot een oplossing komen. Dit blijkt ook uit het eerdergenoemde evaluatieonderzoek van de Wfw. Van de mogelijkheid om thuiswerken bij cao te regelen werd tot recent niet veel gebruik gemaakt. ${ }^{23}$ Mogelijk is evenwel een verandering aanstaande. Uit een onderzoek dat werkgeversvereniging $A W V N$ op verzoek van NU.nl gedaan heeft, blijkt dat (de verschillende aspecten van) thuiswerken als gevolg van de COVID-19-pandemie bij zowel werkgevers als werknemers inmiddels bovenaan de lijstjes van het cao-overleg staat. ${ }^{24}$

De voorgestelde aanpassing is (daarnaast) dusdanig ingrijpend voor werkgevers dat het in onze optiek verdere aanpassing behoeft. Uit verschillende kritische reacties op de internetconsultatie blijkt dat zorgen bestaan over onder meer de situatie dat de werknemer de werkzaamheden vanuit (het thuiswerkadres in) het buitenland wenst te verrichten. Dit kan voor een werkgever tot gevolg hebben dat hij een kostbare payroll in het betreffende land moet opzetten, alsmede dat arbeidsrechtelijke, fiscale en socialezekerheidsrechtelijke regimes van andere landen van toepassing blijken. Om nog maar te zwijgen over de kosten van (juridisch) advies die een werkgever zal moeten maken om aan de regelgeving van het land in kwestie te voldoen. Ook dient gedacht te worden aan de problematiek in het geval van arbeidsongeschiktheid, controle daarop en reintegratie.

Met Vegter zijn wij van mening dat het de essentie van de gezagsverhouding aantast indien een werknemer (tegen de wil van de werkgever) kan bepalen waar hij werkt. ${ }^{25}$ Daarnaast achten we het onredelijk dat de gevolgen en risico's van de arbeidsplaatskeuze van de werknemer vervolgens voor rekening en risico van de werkgever komen.

22. Zie ook M.S.A. Vegter, 'Wet werken waar je wil(t)', TAC maart 2021.

23. Uit een representatieve steekproef waarbij 97 cao's zijn onderzocht, blijkt dat in de helft van deze cao's (slechts) verwezen wordt naar de Wfw, waarbij het in de meeste gevallen gaat om de aanpassing van de arbeidsduur. Tevens blijkt dat sinds 2016 niet vaker naar de Wfw wordt verwezen in cao's (Rapport Arbeid en Zorg 2019, Ministerie van SZW, september 2020).

24. 'Thuiswerken is steeds vaker onderdeel van de arbeidsvoorwaarden', www.nu.nl, 6 mei 2021

25. M.S.A. Vegter, 'Wet werken waar je wil(t)', TAC maart 2021
De Raad van State heeft advies over het wetsvoorstel uitgebracht, ${ }^{26}$ waarna op 16 maart 2021 een aangepast wetsvoorstel bij de Tweede Kamer is ingediend. ${ }^{27}$ De Raad van State is niet overtuigd van de noodzaak van het wetsvoorstel. Wetgeving komt pas in beeld als zich structureel knelpunten voordoen in de praktijk. Vooralsnog blijkt niet van een zodanig probleem dat de wetgever moet ingrijpen, aldus de Raad van State. Het is aan de werkgever en de werknemer om afspraken te maken over arbeidsaangelegenheden. Tevens is een rol weggelegd voor de sociale partners in het kader van, bijvoorbeeld, de cao-praktijk. Over de structurele ontwikkeling rond thuiswerken bestaat ook nog veel onduidelijkheid. Het wetsvoorstel veronderstelt verder dat het in beginsel aan de werknemer is om te bepalen waar de werkzaamheden worden verricht. De Raad van State vraagt zich af of dat uitgangspunt voldoende recht doet aan de primaire taak en verantwoordelijkheid van de werkgever om de arbeid te organiseren. Daarnaast is het volgens de Raad van State op voorhand niet duidelijk dat dit wetsvoorstel een bijdrage levert aan het faciliteren van de dialoog tussen werkgever en werknemer. Ten slotte is volgens de Raad van State meer inzicht nodig in de lasten van het voorstel voor werkgevers en moet duidelijk zijn in welke situaties kosten een aanvaardbare reden kunnen zijn om een verzoek tot wijziging van de werkplek af te wijzen.

Gezien de kritische reacties naar aanleiding van de internetconsultatie ten anzien van de locatie van de werkplek is het wetsvoorstel aangepast door de wijziging van de arbeidsplaats te beperken tot het werken op een werklocatie die de werkgever ter beschikking stelt of het woonadres van de werknemer, mits dat woonadres op het grondgebied van de Europese Unie ligt. De aanpassing van het wetsvoorstel op dit punt neemt de geschetste bezwaren ten aanzien van de problematiek van werknemers met een thuiswerkadres in het buitenland slechts gedeeltelijk weg. De initiatiefnemers van het wetsvoorstel erkennen dat de geschetste problematiek niet met het wetsvoorstel kan worden geregeld en roepen de regering op om met landen in gesprek te gaan ter versoepeling van de regels met betrekking tot belastingen premieplicht. De Raad van State heeft opgemerkt dat de wijziging een anzienlijke inperking inhoudt ten opzichte van de huidige wetgeving en praktijk op grond waarvan een verzoek van een werknemer op elke gewenste arbeidsplaats betrekking kan hebben en adviseerde daarom het voorstel op dit punt aan te passen.

Het wetsvoorstel is op 12 mei 2021 behandeld door de commissie SZW van de Tweede Kamer, belast met het voorbereidend onderzoek van het wetsvoorstel. De commissie SZW heeft op 17 mei 2021 verslag uitgebracht van de vragen en opmerkingen van de verschillende fracties. ${ }^{28}$ De vragen over onder meer het nut en de noodzaak van het wetsvoorstel, alsmede over de neven-

26. Kamerstukken // 2020/21, 35714, nr. 4

27. Kamerstukken // 2020/21, 35714, nr. 5

28. Kamerstukken // 2020/21, 35714, nr. 8. 
effecten ervan voor werkgevers, werknemers, de samenleving en het milieu blijven bestaan. Onder het voorbehoud dat de in het verslag opgenomen vragen afdoende door de initiatiefnemers zullen worden beantwoord, acht de vaste commissie SZW de openbare behandeling van het wetsvoorstel voldoende voorbereid. ${ }^{29}$

2.4 Overheidsadvies: recht op thuiswerken? Vooralsnog kan een werkgever een verzoek van een werknemer om de werkzaamheden vanuit huis te verrichten dus betrekkelijk eenvoudig afwijzen. Kan, gezien het overheidsadvies ten aanzien van thuiswerken, momenteel evenwel gesproken worden van een recht op thuiswerken?

Dat is niet het geval, aldus de kantonrechter te Nijmegen. ${ }^{30}$ In deze zaak verzocht de werknemer haar werkgever om haar thuis te laten werken, hetgeen door de werkgever werd geweigerd. Volgens de werknemer handelde de werkgever daarmee in strijd met onder meer het beginsel van goed werkgeverschap, zijn instructiebevoegdheid en zijn zorgplicht. De kantonrechter zag dat anders. Volgens de kantonrechter grijpt het zeer algemeen geformuleerde advies van de overheid om zo veel mogelijk thuis te werken niet zo ver in op de rechtsverhouding tussen werkgever en werknemer dat de werknemer daaruit een recht op thuiswerken kan ontlenen. De stelling van de werknemer dat het overheidsadvies de instructiebevoegdheid van de werkgever inperkt en/of op grond van de redelijkheid en billijkheid zonder meer door een goed werkgever moet worden gevolgd, hield geen stand. Verder achtte de kantonrechter het voldoende aannemelijk dat de werkgever passende COVID-19maatregelen getroffen had en dat de werknemer nodig was op de werkvloer. De Wfw was in deze zaak overigens niet van toepassing, in verband met het geringe aantal werknemers. Gezien de 'duty to consider' zou een toets op grond van de Wfw echter niet tot een ander oordeel hebben geleid.

Een uitspraak van de kantonrechter Maastricht laat evenwel zien dat een werknemer onder omstandigheden van de werkgever kan verlangen thuis te werken. ${ }^{31} \mathrm{De}$ werknemer, een secretaresse/receptioniste, kampte met chronisch hartfalen en behoorde als gevolg daarvan tot de risicogroep. Ondanks dat de bedrijfsarts adviseerde de werknemer thuis te laten werken, riep de werkgever werknemer op om - net als haar collega's - op kantoor te komen werken. De werknemer meldde zich ziek waarna een discussie ontstond over de vraag of de werkplek veilig was en over de wens van de werknemer om thuis te werken. De werknemer stelde zich op het standpunt dat er onvoldoende beschermingsmaatregelen waren getroffen, waardoor geen sprake was van een veilige werkomgeving. $\mathrm{Zij}$ bood aan om de werkzaamheden (al dan niet aangepast) vanuit huis te verrichten, waarbij zij zelfs bereid was om de kosten te dragen van het aanpassen van haar werkplek. De bedrijfsarts ondersteunde het standpunt van de werknemer dat zij ziek was en dat de door de werkgever getroffen beschermingsmaatregelen niet op orde waren. De werkgever stelde zich desalniettemin op het standpunt dat sprake was van werkweigering en staakte de loonbetaling. Daarop vorderde de werknemer in kort geding achterstallig loon. De rechter was van oordeel dat de werknemer niet kon worden tegengeworpen dat zij niet op het werk wilde verschijnen. Van werkweigering was geen sprake. Daarnaast was volgens de kantonrechter niet gebleken dat de werkgever werkzaamheden had aangeboden die de werknemer wel vanuit huis had kunnen verrichten. De loonvordering werd dan ook toegewezen.

Het overheidsadvies is sinds bovengenoemde uitspraken aangescherpt. 'Werk thuis, tenzij het niet anders kan' in plaats van 'Werk zoveel mogelijk thuis'. Naar ons oordeel maakt het aangescherpte advies niet dat inmiddels wel zou kunnen worden gesproken van een recht op thuiswerken. Het blijft immers een (weliswaar dringend) advies van de overheid. Een werkgever heeft in onze optiek in beginsel nog altijd de bevoegdheid om werknemers in verband met de aard van de werkzaamheden te instrueren op het werk te verschijnen. Voorwaarde is wel dat voldoende beschermingsmaatregelen zijn getroffen en dat sprake is van een veilige en gezonde werkplek.

Houweling merkt op dat voor toekomstige zaken over het 'recht' op thuiswerken inspiratie kan worden opgedaan uit de (oude) re-integratiejurisprudentie van de Hoge Raad. Om werknemers optimaal te faciliteren om zo veel mogelijk aan het werk te blijven, mag onder omstandigheden van een werkgever worden gevergd bepaalde bedrijfsprocessen aan te passen. Dat kent uiteraard grenzen, bijvoorbeeld indien het thuiswerken van de ene collega leidt tot overbelasting van op de werklocatie werkende collega's met fysiek zwaar werk. ${ }^{32}$

2.5 Overheidsadvies: plicht om thuis te werken? Een recht op thuiswerken bestaat in beginsel dus niet. Hoe zit het met de omgekeerde situatie; kan een werknemer door zijn werkgever worden verplicht om thuis te werken, in het licht van de COVID-19-pandemie?

Werkgevers moeten er gezien het dringende overheidsadvies voor zorgen dat werknemers zo veel mogelijk thuiswerken, tenzij het niet anders kan. Momenteel geldt dus dat werknemers in beginsel verplicht zijn te voldoen aan een mededeling van de werkgever dat voorlopig moet worden thuisgewerkt. Een werknemer is immers verplicht om zich te houden aan voorschriften van de werkgever omtrent het verrichten van de arbeid en aan voorschriften met betrekking tot de goede orde in de onderneming. Dit vloeit voort uit het instructierecht 
van de werkgever, maar ook uit het beginsel van goed werkgever- en werknemerschap. ${ }^{33}$ Werkgevers zijn verantwoordelijk voor een gezonde en veilige werkomgeving. Daarbij dient een werkgever rekening te houden met het belang van alle werknemers.

Een werknemer die op grond van de richtlijnen van het RIVM in quarantaine moet omdat hij in nauw contact is geweest met iemand die besmet is met COVID-19, kan worden verplicht om thuis te werken. Uiteraard voor zover sprake is van arbeidsgeschiktheid van de werknemer. De vraag is vervolgens voor wiens rekening en risico dit komt en wat de eventuele gevolgen zijn voor de betaling van het loon van de werknemer. Indien daadwerkelijk thuis kan worden gewerkt, is het antwoord op deze vraag eenvoudig. Maar wat geldt als de werkzaamheden zich er niet voor lenen om vanuit huis te worden verricht? Uit verschillende uitspraken waarin dit speelde, volgt dat ook in dat geval de werknemer recht houdt op betaling van het loon. Het niet kunnen werken komt op grond van artikel 7:628 BW dan voor rekening en risico van de werkgever. ${ }^{34}$

Er zijn echter situaties denkbaar waarin het minder voor de hand ligt dat de quarantaine voor rekening en risico van de werkgever komt. In het geval dat een werknemer zich bijvoorbeeld na vijf dagen quarantaine niet wil laten testen en als gevolg daarvan nog eens vijf dagen in quarantaine moet, is het naar ons oordeel in beginsel niet redelijk dat deze verlengde quarantaineperiode voor rekening van de werkgever komt. ${ }^{35}$

Op 25 mei 2021 is het wetsvoorstel Quarantaineplicht aangenomen. ${ }^{36}$ Dit betekent onder meer dat per 1 juni 2021 een algemene quarantaineplicht geldt van in ieder geval vijf dagen voor reizigers uit aangewezen hoogrisicogebieden. Naar verwachting zal het risico van het niet kunnen werken als gevolg van een dergelijke quarantaine voor rekening van werknemers komen, aldus ook Besselink. ${ }^{37}$

Bovenstaande leidt echter niet tot de conclusie dat een werknemer kan worden verplicht ook na de COVID-19pandemie permanent thuis te werken. De pandemie en het dringende overheidsadvies maken naar onze mening dat sprake is van een uitzonderlijke, tijdelijke, situatie op grond waarvan in beginsel van een werknemer kan worden verlangd vanuit huis te werken. Op het moment dat thuiswerken niet langer de overheidsnorm is, gelden de gewone regels. De arbeidsplaats kan dan, indien

33. Art. 7:660 BW en 7:611 BW.

34. Zie bijv. Ktr. Maastricht 23 juni 2020, ECLI:NL:RBLIM:2020:4465 en Ktr. Alkmaar 27 juli 2020, ECLI:NL:RBNHO:2020:5863 en E. Akopova en L. van den Heuvel, 'Arbeidsrecht in tijden van corona', ArbeidsRecht 2021/13.

35. Op grond van de RIVM-richtlijnen moet iemand die in nauw contact is geweest met een besmet persoon, gedurende 10 dagen in quarantaine. Voor huisgenoten en nauwe contacten is het mogelijk om zich vanaf dag 5 van de quarantaineperiode te laten testen. Bij een negatieve test hoeft men niet langer in quarantaine.

36. Wijziging van de Wet publieke gezondheid vanwege de invoering van aanvullende tijdelijke maatregelen voor het internationaal personenverkeer in verband met de bestrijding van de epidemie van covid-19, Kamerstukken // 2020/21, 35808, nr. 2.

37. Zie P.J.B.M. Besselink, in 'Werknemer draait op voor extra vrije dagen bij quarantaineplicht', RTL Nieuws, 1 mei 2021. sprake is van een arbeidsvoorwaarde, slechts eenzijdig door de werkgever worden gewijzigd indien voldaan is aan artikel 7:611 $\mathrm{BW}$ dan wel artikel 7:613 $\mathrm{BW}$, zoals eerder aan de orde is gekomen. Dat is niet snel het geval. Hierbij is ook artikel 8 EVRM (recht op eerbiediging van privéleven) relevant. ${ }^{38}$

\subsection{Algemene Criteria Thuiswerken}

Bij brief van 24 februari 2021 heeft de Minister van SZW de Tweede Kamer geinformeerd over de 'Algemene Criteria Thuiswerken'. ${ }^{39}$ Deze criteria zijn door de minister en de sociale partners opgesteld en vormen een handvat voor individuele werkgevers en werknemers bij het maken van afwegingen of een werknemer thuis of op een werklocatie kan werken. Het is aan werkgevers om samen met de medezeggenschapsraad beleid rond thuiswerken uit te werken. Onveilige werksituaties kunnen worden gemeld bij het meldpunt van de Inspectie SZW. De Inspectie SZW zal, waar nodig met andere toezichthouders, door middel van een breed palet aan interventies opvolging geven aan meldingen over het niet opvolgen van het dringende advies om thuis te werken. De Inspectie SZW handhaaft dus reactief.

Er worden vijf criteria genoemd voor wanneer een werknemer geheel of gedeeltelijk op een werklocatie kan werken. De criteria zijn uitgewerkt en er worden alternatieven genoemd voor situaties waarin niet aan de criteria wordt voldaan. De criteria luiden als volgt.

1. De werkzaamheden behoeven (deels) fysieke aanwezigheid van de werknemer en die is strikt noodzakelijk voor de voortgang van een noodzakelijk bedrijfsproces of om dringende sociale redenen (zoals in de bouw of hulpverlening).

2. De werkzaamheden behoeven (deels) locatiegebonden software of hardware.

3. De werkzaamheden behoeven (deels) het gebruik van bedrijfsvertrouwelijke informatie die enkel op locatie in te zien is.

4. De werknemer ervaart dusdanige mentale klachten dat het (deels) uitvoeren van de werkzaamheden op locatie noodzakelijk is voor de mentale gezondheid van de werknemer.

5. De fysieke thuiswerksituatie van de werknemer is niet toereikend en kan ook niet toereikend gemaakt worden, waardoor het (deels) uitvoeren van de werkzaamheden op locatie noodzakelijk is voor de gezondheid en het welbevinden van de werknemer.

Uit de brief van de Minister van SZW blijkt dat sinds januari 2021432 meldingen door de Inspectie SZW zijn ontvangen over (het niet mogen) thuiswerken, waarvan er 376 verder onderzocht worden. In een groot deel heeft inmiddels een eerste interventie plaatsgevonden. De Inspectie SZW zal de criteria bij haar interventies betrekken. Niet-thuiswerken op zichzelf is geen over-

38. A.R. Houweling, 'Corona en arbeidsrecht: hoe NOW verder met loon en werkplek?!', MvV 2020, nr. 9

39. Algemene Criteria Thuiswerken, 'Werk thuis tenzij het niet anders kan', Nationaal Kernteam Crisiscommunicatie (NKC), februari 2021 
treding, een ongezonde en onveilige arbeidsplaats is dat echter wel.

\section{Thuiswerken en ontslag}

COVID-19 heeft ook tot interessante uitspraken geleid op het gebied van het ontslagrecht. ${ }^{40}$ De jurisprudentie is erg casuistisch en vooralsnog volgt daaruit geen verschuiving in de beoordeling bij bijvoorbeeld een ontslag op staande voet. ${ }^{41}$

In een aantal ontslagzaken speelde een verschil van mening over de vraag of thuis of op de werklocatie gewerkt moest worden. De uitspraak van de kantonrechter Rotterdam ging om een werknemer die tot de risicogroep behoorde en paniekaanvallen ondervond vanwege zorgen over COVID-19. ${ }^{42}$ De werknemer werkte van maart tot juni 2020 volledig vanuit huis. Vanaf juli 2020 diende zij weer op kantoor te werken. Vlak daarvoor werd zij geïnformeerd over een collega die besmet was met COVID-19, maar inmiddels was hersteld. De werknemer kaartte haar zorgen over de besmettelijkheid van de collega aan bij haar werkgever en liet weten liever niet naar kantoor te komen als de collega er ook was. De werknemer werd vervolgens geschorst, omdat er volgens de werkgever sprake was van werkweigering. Een mediationtraject bood geen oplossing. Uiteindelijk heeft de werkgever de kantonrechter verzocht de arbeidsovereenkomst op grond van de g-grond (verstoorde arbeidsverhouding) te ontbinden. Omdat partijen het erover eens waren dat sprake was van een verstoorde arbeidsverhouding, werd de arbeidsovereenkomst door de kantonrechter ontbonden onder toekenning van de transitievergoeding. Daarnaast is een billijke vergoeding toegekend van $€ 6.500$ bruto. De kantonrechter was van oordeel dat de werkgever ernstig verwijtbaar had gehandeld door onvoldoende begrip te tonen voor de angst van de werknemer om besmet te raken. De kantonrechter oordeelde dat sprake was van een situatie waarin de werkgever een voorval dat niet ontslagwaardig was, aangreep om een verstoorde arbeidsrelatie te creëren en op beëindiging van de arbeidsovereenkomst aan te sturen. Daarbij werd ook meegewogen dat de werkgever zich onvoldoende had ingespannen om de verstoorde arbeidsverhouding te herstellen.

Ook in de uitspraak van de kantonrechter Almere bestond discussie tussen de werknemer en de werkgever over de door de werkgever gehanteerde COVID-19aanpak. ${ }^{43}$ De werkgever nam de pandemie niet erg serieus door de werknemers ervan te weerhouden vanuit huis te werken en in strijd met de RIVM-richtlijnen in

40. Zie voor een overzicht en analyse P.J.B.M. Besselink, 'Kroniek coronaarbeidsrechtspraak', TAP 2020/190.

41. E. Akopova en L. van den Heuvel, 'Arbeidsrecht in tijden van corona', ArbeidsRecht 2021/13.

42. Ktr. Rotterdam 14 januari 2021, ECLI:NL:RBROT:2021:255

43. Ktr. Midden-Nederland 15 maart 2021, ECLI:NL:RBMNE:2021:1170. het coronaprotocol op te nemen dat werknemers toch naar het werk moesten komen indien een huisgenoot last had van koorts en/of benauwdheid. De werknemer was het daar niet mee eens. De werknemer meldde zich ziek, waarop een beëindigingsovereenkomst werd aangeboden en een vacature werd geplaatst voor de functie van de werknemer. Ook de ziekmelding van de werknemer werd betwist. De bedrijfsarts oordeelde dat sprake was van een arbeidsconflict en adviseerde de werknemer om het werk vanuit huis te hervatten, hetgeen de werkgever niet toeliet. De loonbetaling werd gestaakt en er werd een verzoek tot ontbinding van de arbeidsovereenkomst ingediend. Primair op grond van verwijtbaar handelen van de werknemer (e-grond) en subsidiair op grond van een verstoorde arbeidsverhouding (g-grond). Aangezien de werknemer tijdens de mondelinge behandeling te kennen gaf zich wegens zijn gezondheid niet te verzetten tegen ontbinding op de g-grond, werd de arbeidsovereenkomst op die grond ontbonden. De kantonrechter was van mening dat sprake was van ernstige verwijtbaarheid aan de zijde van de werkgever en kende naast de transitievergoeding een billijke vergoeding toe. De werkgever had naar zijn oordeel onzorgvuldig en nalatig gehandeld ten aanzien van de RIVM-richtlijnen, door direct na de ziekmelding van de werknemer aan te sturen op beëindiging van de arbeidsovereenkomst, door het advies van de bedrijfsarts te negeren, het loon stop te zetten en door zich onvoldoende in te spannen om de arbeidsrelatie te herstellen. Een terechte en voor de werkgever bittere uitspraak met een prijskaartje van in totaal ruim $€ 100.000$ bruto.

Bovengenoemde uitspraken zijn voorbeelden van situaties waarin discussie bestaat over de vraag of er reden is om vanuit huis te werken. De Algemene Criteria Thuiswerken hebben tot doel dergelijke discussies zo veel mogelijk te voorkomen. De criteria zijn nuttige handvatten, hoewel wij ons kunnen voorstellen dat hier in de praktijk alsnog een verschil van mening over ontstaat.

Opvallend is dat sinds het uitbreken van de pandemie, voor zover ons bekend, nog geen jurisprudentie is verschenen over een thuiswerksituatie die tot ontslag op de d-grond (disfunctioneren) heeft geleid. Thuiswerken vergt een andere, over het algemeen meer zelfstandige, manier van werken. Voor werknemers die niet voldoende functioneren en meer begeleiding nodig hebben, kan dat problematisch zijn. Het doorlopen van een verbetertraject op afstand vergt extra inspanningen van zowel de werkgever als de werknemer. De ongemotiveerde werknemer, die de nadruk meer op thuis legt dan op merken, lijkt beter te gedijen in de pandemie. Via via bereikten ons verhalen over werknemers die een Worddocument openen en een boek op de spatieknop leggen zodat zij in Microsoft Teams actief lijken. Het kan niet anders dan dat we dergelijke kwesties in de jurisprudentie zullen tegenkomen. Laatstgenoemd voorbeeld zal in geval van ontbinding van de arbeidsovereenkomst in onze optiek overigens eerder een e-grond (verwijtbaar 
handelen of nalaten) dan een d-grond opleveren. Daarbij zal een rol spelen of en in hoeverre een werkgever een werknemer mag monitoren. ${ }^{44}$

\section{Thuiswerken en arbeidsomstandigheden}

Ondanks dat uit een enquête van vakbond CNV blijkt dat ruim $40 \%$ van de ondervraagde leden nog regelmatig naar het werk gaat, wordt momenteel massaal thuisgewerkt. ${ }^{45}$ Volgens een onderzoek van het Kennisinstituut voor Mobiliteitsbeleid (KiM) was het aantal thuiswerkers begin 2021 ongeveer $50 \%{ }^{46}$ Het is de verwachting dat ook indien de overheidsmaatregelen versoepeld worden en we weer naar kantoor mogen, we voortaan een aanzienlijk deel van de arbeidsomvang thuis zullen werken. ${ }^{47}$

Werkgevers hebben niet altijd evenveel aandacht voor het Arbo-technische deel van het thuiswerken. Er wordt nog altijd veel aan keukentafels en op iPads gewerkt en uit een onderzoek van CNV onder ruim 2.600 thuiswerkende leden blijkt dat sprake is van een aanzienlijke toename van de nek- en schouderklachten sinds er wordt thuisgewerkt. ${ }^{48}$ Ruim $41 \%$ heeft vaker last van fysieke klachten en $44 \%$ beschikt niet over een werkplek die aan de Arbowetgeving voldoet. Dat is zorgwekkend.

\subsection{Arbowetgeving}

De zorg voor goede arbeidsomstandigheden is opgenomen in de Arbeidsomstandighedenwet ${ }^{49}$ en is verder uitgewerkt in het Arbeidsomstandighedenbesluit en de Arbeidsomstandighedenregeling. Thuiswerk valt onder 'plaatsonafhankelijke arbeid'. ${ }^{50}$ Voor plaatsonafhankelijke arbeid geldt een verlicht Arbo-regime, waardoor bepaalde regels uit hoofdstuk 3 van het Arbeidsomstandighedenbesluit niet van toepassing zijn, waaronder regels inzake nooduitgangen en brandgevaar. ${ }^{51}$ Een werkgever dient echter wel zorg te dragen voor de inrichting van een ergonomische werkplek thuis. ${ }^{52} \mathrm{Zo}$ zijn de bepalingen inzake de inrichting van de beeldschermwerkplek onverkort van toepassing op plaatsonafhankelijke arbeid. ${ }^{53}$ Dit is slechts anders indien dat redelijkerwijs niet van de werkgever kan worden

44. De (on)mogelijkheden van het monitoren van werknemers die thuis werken, wordt in deze bijdrage niet behandeld.

45. Het Parool, 16 januari 2021.

46. Onderzoek 'Thuiswerken tijdens en na de coronacrisis', KiM januari 2021.

47. NRC 1 januari 2021, 'Als het straks weer mag, werken we maar de helft op kantoor'.

48. CNV-onderzoek: thuiswerker vaker last van fysieke klachten, 26 oktober 2020.

49. Hoofdregel art. 3 Arbeidsomstandighedenwet.

50. Hoofdstuk 1, afdeling 10 Arbeidsomstandighedenbesluit.

51. Zie ook M. ten Broeke en I. Baijens, 'Werken vanuit huis: het juridisch kader', ArbeidsRecht 2019/28.

52. Art. 1.47 lid 2, art. 5.4 jo. 5.12 Arbeidsomstandighedenbesluit.

53. Hoofdstuk 5 Arbeidsomstandighedenregeling. verlangd. ${ }^{54}$ De kosten die een werkgever maakt voor de naleving van de Arbowetgeving mogen niet ten laste van de werknemer komen. ${ }^{55}$

Werknemers moeten regelmatig en actief over gezond werken en de inrichting van de werkplek worden geïformeerd door de werkgever, bijvoorbeeld door middel van een beeldschermwerkinstructie, instructiefilmpjes en een infographic op het intranet. Er is sprake van een voortdurende zorgplicht, een eenmalige (beeldschermwerk)instructie is dus niet voldoende.

De werkgever moet de werkplek thuis controleren. ${ }^{56}$ Met de werknemer kan worden overeengekomen dat de werkplek thuis wordt bezichtigd. Een andere optie is controle van foto- en/of filmmateriaal van de werkplek thuis. Controle kan in onze optiek tevens plaatsvinden door periodiek een door de werknemer in te vullen en te ondertekenen checklist te verstrekken, waarin de verschillende onderdelen van een ergonomische werkplek zijn opgenomen. De Inspectie SZW is bevoegd om werkplekken, waaronder de werkplek thuis, te controleren. ${ }^{57}$ Indien sprake is van een overtreding van de regels, kan de Inspectie SZW handhavend optreden door middel van het geven van waarschuwingen, het opleggen van boetes en het stilleggen van werkzaamheden.

Naast de zorg voor een ergonomische werkplek dient een werkgever te zorgen voor arbeidsomstandighedenbeleid teneinde psychosociale arbeidsbelasting te beperken. ${ }^{58}$ Het gaat daarbij onder meer om het voorkomen dan wel beperken van werkdruk, een belangrijk aandachtspunt bij thuiswerken. Onderdeel van het arbeidsomstandighedenbeleid is een risico-inventarisatie en -evaluatie. ${ }^{59}$

Niet alleen de werkgever maar ook de werknemer heeft verplichtingen uit hoofde van de Arbowetgeving. De werknemer is verplicht om op de arbeidsplaats naar vermogen te zorgen voor zijn eigen veiligheid en gezondheid en die van de andere betrokken personen. Uitvoering van het arbeidsomstandighedenbeleid is dus een gezamenlijke taak van de werkgever en de werknemer, waarbij ook een rol is weggelegd voor de ondernemingsraad, de personeelsvertegenwoordiging, dan wel de belanghebbende werknemers. ${ }^{60}$

In verband met de COVID-19-pandemie zijn de Arbeidsomstandighedenwet en het Arbeidsomstandighedenbesluit tijdelijk gewijzigd. ${ }^{61}$ In de Arbeidsomstan-

\footnotetext{
54. Art. 5.4 Arbeidsomstandighedenbesluit.

55. Art. 44 Arbeidsomstandighedenwet.

56. Met inachtneming van art. 12 Grondwet.

57. Art. 24 lid 3 Arbeidsomstandighedenwet.

58. Art. 3 lid 2 Arbeidsomstandighedenwet.

59. Art. 5 Arbeidsomstandighedenwet.

60. Art. 11 jo. 12 Arbeidsomstandighedenwet, art. 28 WOR.

61. Wet van 28 oktober 2020, Tijdelijke wet maatregelen covid-19 en besluit van 25 november 2020, houdende tijdelijke wijziging van het Arbeidsomstandighedenbesluit en het Arbeidsveiligheidsbesluit I Bes in verband met de bestrijding van het coronavirus (SARS-CoV-2), Stb. 2020, 483.
} 
dighedenwet is een zevende lid aan artikel 28 toegevoegd, waarin is bepaald dat sprake is van ernstig gevaar als maatregelen ter voorkoming of beperking van COVID-19 in ernstige mate niet worden getroffen. In dat geval mag het werk worden stilgelegd. Het Arbeidsomstandighedenbesluit is uitgebreid met artikel $3.2 \mathrm{~A}$ 'Tijdelijke aanvullende vereisten in verband met de bestrijding van de epidemie COVID-19'. Op grond van dit artikel dienen specifiek ter voorkoming van een COVID-19-besmetting van werknemers en derden op arbeidsplaatsen tijdig de daarvoor noodzakelijke maatregelen en voorzieningen te worden getroffen. De wijzigingen in de Arbeidsomstandighedenwet en het Arbeidsomstandighedenbesluit zijn op 1 december 2020 in werking getreden voor de duur van drie maanden. Bij koninklijk besluit van 18 februari 2021 is de werkingsduur verlengd tot 1 juni $2021 .^{62}$

Op 21 juli 2020 is een wetsvoorstel ingediend tot wijziging van de Arbeidsomstandighedenwet in verband met het aangaan van een gesprek tussen werkgever en werknemers over bereikbaarheid buiten werktijd. ${ }^{63} \mathrm{De}$ Raad van State heeft op 23 september 2020 advies uitgebracht. ${ }^{64}$ Naar aanleiding van het advies van de Raad van State is op 20 mei 2021 een gewijzigd wetsvoorstel ingediend. ${ }^{65}$ De Raad van State acht het wetsvoorstel overigens onnodig, nu de Arbeidsomstandighedenwet reeds een bepaling bevat op grond waarvan werkgevers en werknemers maatregelen moeten nemen ter beheersing van psychosociale arbeidsbelasting.

\subsection{Reikwijdte Arbowetgeving}

Welke medewerkers worden als werknemer in de zin van de Arbowetgeving beschouwd? De definitie van de begrippen 'werkgever' en 'werknemer' in de Arbowetgeving is aanzienlijk ruimer dan die in bijvoorbeeld het BW. ${ }^{66}$

\section{- Werknemers, stagiairs en vrijmilligers}

Werknemers in de zin van artikel 7:610 BW vallen onder de reikwijdte van de Arbowetgeving. Dat geldt tevens voor stagiairs, indien zij onder gezag arbeid verrichten. Vrijwilligers zijn in beginsel echter (grotendeels) uitgezonderd. ${ }^{67}$

\section{- Uitzendkrachten en gedetacheerden}

Uitzendkrachten en gedetacheerden vallen tevens onder de reikwijdte van het begrip werknemer, in die zin dat de inlenende organisatie als werkgever wordt beschouwd. ${ }^{68}$ Achterliggende reden is onder meer dat de inlener invloed heeft op de arbeidsomstandigheden

62. Stb. 2021, 93.

63. Voorstel van wet van het lid Gijs van Dijk tot wijziging van de Arbeidsomstandighedenwet in verband met het aangaan van een gesprek tussen werkgever en werknemers over bereikbaarheid buiten werktijd (Wet op het recht op onbereikbaarheid). Zie tevens over dit wetsvoorstel M.S.A. Vegter, 'Wet werken waar je wil(t)', TAC maart 2021.

64. Kamerstukken // 2020/21, 35536, nr. 4

65. Kamerstukken I/ 2020/21, 35536, nr. 5 en 6 (MvT).

66. Art. 1 lid 1 a sub 1 en 2 Arbeidsomstandighedenwet.

67. Art. 1 lid 2a sub 1 Arbeidsomstandighedenwet en art. 1 lid 2b Arbeidsomstandighedenwet.

68. Art. 1 lid 1 a sub 1 en 2 Arbeidsomstandighedenwet. waaronder gewerkt wordt. Daarnaast werkt de uitzendkracht of gedetacheerde onder zijn gezag en dient hij gehoor te geven aan opdrachten van de inlener die hem in potentieel gevaarlijke omstandigheden brengen.

Het is de vraag of voorgaande redenen nog opgaan gedurende de COVID-19-pandemie. We werken momenteel in beginsel veelal thuis en de inlener heeft geen, althans aanzienlijk minder invloed op de arbeidsomstandigheden aldaar. Wij menen dan ook dat het in de huidige omstandigheden in redelijkheid niet van een inlener kan worden verlangd om (volledig) zorg te dragen voor een ergonomische thuiswerkplek voor ingeleend personeel. ${ }^{69} \mathrm{Op}$ grond van de redelijkheid en billijkheid dienen uitlenende organisaties in onze optiek zelf zorg te dragen voor de inrichting van de thuiswerkplek van hun werknemers, althans in ieder geval voor het merendeel van de kosten daarvan. Inlenende organisaties kunnen ervoor kiezen nog slechts personeel in te lenen dat al over een ergonomische werkplek beschikt en daartoe een verklaring ondertekent.

Indien een werkgever aan zijn werknemers een vergoeding beschikbaar stelt voor de inrichting van de werkplek, dan is het volgende van belang. Uitzendkrachten en gedetacheerden hebben op grond van artikel 8 Waadi en artikel 16 van de cao voor uitzendkrachten recht op de inlenersbeloning. Daaronder vallen, naast het loon, ook (noodzakelijke) kostenvergoedingen. De kans is reëel dat een vergoeding van de kosten van de inrichting van een werkplek onder de inlenersbeloning valt.

- Zzp'ers

Een (echte) zzp'er valt in beginsel niet onder de Arbeidsomstandighedenwet, gezien de definitie van werkgever en werknemer in deze wet. $\mathrm{Bij}$ algemene maatregel van bestuur kan evenwel worden bepaald dat voorschriften van de wet of daarop berustende bepalingen tevens van toepassing zijn op een zzp'er (en een vrijwilliger), voor zover zij betrekking hebben op onder meer arbeid waaraan bijzondere gevaren voor de veiligheid of gezondheid zijn verbonden. ${ }^{70}$ In het Arbeidsomstandighedenbesluit is opgenomen welke artikelen van de Arbeidsomstandighedenwet op de zelfstandige van toepassing zijn. ${ }^{71}$ Daarbij geldt een onderscheid tussen de meewerkende zelfstandigen en zelfstandigen die alleen werken. ${ }^{72}$

Het is derhalve aan te bevelen om (ook) de zzp'er te laten verklaren dat hij uit eigen hoofde over een ergonomische werkplek beschikt, zeker met het oog op eventuele aansprakelijkheid van de 'werkgever'.

69. Art. 5.4 Arbeidsomstandighedenbesluit.

70. Art. 16 lid 7 Arbeidsomstandighedenwet.

71. Art. 9.5 Arbeidsomstandighedenbesluit.

72. J.H. Bennaars e.a., De werknemerachtige in het sociaal recht: een verkenning, Deventer: Wolters Kluwer 2018, par. 6.3 en J. Popma en M. Snoep, 'Arbeidsomstandighedenwetgeving voor diverse werkenden', ArbeidsRecht 2017/42 


\subsection{Aansprakelijkheid ex artikel 7:658 BW}

Naast de zorgplicht uit de hierboven genoemde publiekrechtelijke wetgeving, bestaat tevens een civielrechtelijke zorgplicht als opgenomen in artikel 7:658 BW. Op grond van genoemd artikel heeft de werkgever de zorgplicht om de werkplek van de werknemer zodanig in te richten en zodanige maatregelen te nemen als redelijkerwijs nodig is om te voorkomen dat de werknemer schade lijdt in de uitoefening van de werkzaamheden. De werkgever is aansprakelijk voor schade die de werknemer in de uitoefening van de werkzaamheden lijdt indien hij niet kan aantonen dat hij aan de genoemde verplichtingen voldaan heeft. De civielrechtelijke zorgplicht strekt zich tevens uit tot de werkplek thuis. ${ }^{73}$

Een werkgever kan ook aanvoeren dat het wel hebben voldaan aan de zorgplicht de schade niet zou hebben voorkomen. ${ }^{74}$ De werkgever is niet aansprakelijk indien de schade in belangrijke mate het gevolg is van opzet of bewuste roekeloosheid van de werknemer. Een beroep hierop slaagt overigens zelden. ${ }^{75}$ Indien sprake is van schending van bijvoorbeeld Arbowetgeving, dan is in de regel sprake van schending van de zorgplicht door de werkgever. ${ }^{76}$ Overigens, ook indien aan alle regelgeving voldaan is, is niet uitgesloten dat sprake is van aansprakelijkheid van de werkgever. ${ }^{77} \mathrm{Er}$ is sprake van dwingend recht, er kan niet ten nadele van de werknemer van worden afgeweken. ${ }^{78}$

In gevallen waarbij artikel 7:658 BW geen soelaas biedt,

bijvoorbeeld omdat het gaat om een situatie die zich niet op de (thuis)werkplek afspeelt, maar wel werkgerelateerd is, kan artikel 7:611 BW in sommige gevallen tot ansprakelijkheid van de werkgever leiden.

De zorgplicht van artikel 7:658 BW richt zich allereerst tot werknemers. Ook andere werkenden kunnen onder de betreffende zorgplicht vallen, zoals ingeleend personeel, stagiairs en vrijwilligers. ${ }^{79}$ Of een zzp'er onder deze zorgplicht valt, moet worden beoordeeld aan de hand van de criteria die volgen uit het Allspan/Davelaar-arrest van de Hoge Raad. ${ }^{80}$ De Hoge Raad concludeerde in dit arrest dat artikel 7:658 lid 4 BW zich voor toepassing leent indien de persoon die buiten dienstbetrekking werkzaamheden verricht, voor de zorg van zijn veiligheid (mede) afhankelijk is van degene voor wie hij de werkzaamheden verricht. Dit hangt af van de omstandigheden van het geval, waaronder meer specifiek de feitelijke verhouding tussen betrokkenen, de aard van de verrichte werkzaamheden en de mate waarin de 'werkgever' invloed heeft op de werkomstandigheden en op de daarmee verband houdende veiligheidsrisico's.

\footnotetext{
3. Hof Amsterdam 7 september 2006, ECLI:NL:GHAMS:2006:AZ5431

HR 21 juni 1974, ECLI:NL:HR:1974:AC5463.

HR 20 september 1996, ECLI:NL:HR:1996:ZC2142.

HR 13 juli 2007, ECLI:NL:HR:2007:BA7355.

HR 5 november 2004, ECLI:NL:HR:2004:AP1463.

Art. 7:658 lid 3 BW.

Art. 7:658 lid 4 BW.

HR 3 maart 2012, ECLI:NL:HR:2012:BV0616.
}

Bij thuiswerken is het lastig vast te stellen of schade tijdens de uitoefening van de werkzaamheden is ontstaan. Anderzijds is het voor werkgevers complexer om uitvoering aan de zorgplicht te geven ten aanzien van de zorgplicht thuis.

Er is (nog) niet veel jurisprudentie over ansprakelijkheid van de werkgever voor schade van de werknemer opgelopen tijdens het werken thuis. De uitspraak die in dit kader veel wordt aangehaald is de uitspraak van het hof Amsterdam uit 2006. ${ }^{81}$ In de betreffende zaak was sprake van een werknemer die arbeidsongeschikt raakte in verband met RSI-klachten aan beide armen, in verband waarmee zij een uitkering ontving op basis van een arbeidsongeschiktheidspercentage van $80-100 \%$. De werknemer verrichtte een substantieel deel van haar werktijd beeldschermwerk vanuit huis. Zowel de kantonrechter als het hof oordeelde dat de werkgever de zorgplicht van artikel 7:658 BW geschonden had en aansprakelijk was voor de schade van de werknemer, omdat de werkgever niet had voldaan aan de verplichtingen die voortvloeien uit de Arbowetgeving. Relevant daarbij was onder meer dat werknemer voorafgaand aan haar werkzaamheden bij werkgever altijd gezond was, zij toestemming had om thuis te werken, de werkdruk door haar als hoog werd ervaren, de werkzaamheden op een niet-ergonomische werkplek (bureaublad gemaakt van een oude deur) werden verricht en niet bleek van een instructie over de risico's van ergonomisch werken/ beeldschermwerk.

\section{Afsluiting}

Een absoluut recht op thuiswerken bestaat (nog) niet en een harde plicht tot thuiswerken (vooralsnog) evenmin. Een werkgever kan een verzoek van een werknemer om aanpassing van de arbeidsplaats tamelijk eenvoudig afwijzen. Indien een werknemer reeds geruime tijd thuis werkt, zal er echter meer handen en voeten moeten worden gegeven aan de onderbouwing van de werkgever dat thuiswerken niet langer mogelijk is. In dat kader zien we de ontwikkelingen van het wetsvoorstel Wet werken waar je wilt met belangstelling tegemoet. De discussie of door een werknemer thuis of op de werklocatie moet worden gewerkt, heeft in een aantal zaken tot het stoppen van de loonbetaling geleid en in enkele gevallen zelfs tot een beëindiging van het dienstverband. Wellicht bieden de door de Minister van SZW opgestelde Algemene Criteria Thuiswerken houvast in dit soort discussies.

Hoe het ook zij, zolang er wordt thuisgewerkt, zal de werkgever moeten zorgen voor een ergonomisch ingerichte werkplek. Voor de verschillende soorten medewerkers gelden in dat kader verschillende verplichtingen, hetgeen gezien de wat ondoorgrondelijke Arbowetgeving niet altijd even inzichtelijk is.

81. Hof Amsterdam 7 september 2006, ECLI:NL:GHAMS:2006:AZ5431 
$\mathrm{Er}$ is het afgelopen jaar al veel COVID-19-jurisprudentie ontstaan en al zijn we begonnen aan de weg terug, het einde van deze ontwikkeling is, mede gezien het beschikbaar worden van vaccins, nog niet in zicht. 